\title{
APLIKASI TECHNOLOGY ACCEPTANCE MODEL PADA SISTEM INFORMASI MANAJEMEN RUMAH SAKIT DI RUMAH SAKIT ORTOPEDI PROF. DR. R. SOEHARSO SURAKARTA
}

\author{
Supriyanti, dan Muhammad Cholil \\ Program Pascasarjana Universitas Sebelas Maret Surakarta, \\ Jl. Ir. Sutami 36 A Surakarta \\ Email: supriyati.rso@gmail.com
}

\begin{abstract}
The purpose of this study to apply the Technology Acceptance Model (TAM) on the Hospital Management Information System. This research is important because changes in hospital management information system (SIMRS) of the old system in collaboration with third parties to the new system is a standalone system that was developed by the IT team RSO Prof. dr. R. Soeharso requires a process of transition, which for some employees lead to conflict in the process of adaptation. This study is an empirical research with quantitative methods. The population of all employees who use information management system as much as 382 people, 193 people sampled with sample random sampling technique. The results of this study include shows, computer selt efficacy influence the perceived usefulness and perceived ease of use of technology in hospital management information system. Subjective norms affect the perceived usefulness and perceived ease of use of technology in hospital management information system. System accessibility while no effect on the perception of the benefits, but the effect on the perceived ease of use of technology in hospital management information system.
\end{abstract}

Keywords: Technology Acceptance Model (TAM), Hospital, Management Information System.

\begin{abstract}
Abstrak
Penelitian ini bertujuan untuk mengaplikasikan Technology Acceptance Model (TAM) pada Sistem Informasi Manajemen Rumah Sakit (SIMRS). Penelitian ini merupakan penelitian empiris dengan metode kuantitatif. Jenis data yang digunakan data primer. Populasi seluruh karyawan yang menggunakan sistem informasi manajemen sebanyak 382 orang, sampel 193 orang dengan teknik sample random sampling. Instrumen penelitian menggunakan kuesioner dengan skala linkert. Hasil penelitian menunjukkan computer selt efficacy berpengaruh terhadap persepsi manfaat dan persepsi kemudahan penggunaan teknologi pada sistem informasi manajemen rumah sakit. Subjective norms berpengaruh terhadap persepsi manfaat dan persepsi kemudahan penggunaan teknologi pada sistem informasi manajemen rumah sakit. System accessibility tidak berpengaruh terhadap persepsi manfaat, namun berpengaruh terhadap persepsi kemudahan penggunaan teknologi pada sistem informasi manajemen rumah sakit. Persepsi kemudahan berpengaruh terhadap persepsi manfaat pada sistem informasi manajemen rumah sakit. Persepsi manfaat dan persepsi kemudahan penggunaan teknologi tidak berpengaruh terhadap sikap menggunakan teknologi pada sistem informasi manajemen
\end{abstract}


rumah sakit. .Sikap dalam menggunakan teknologi berpengaruh terhadap niat untuk menggunakan teknologi pada sistem informasi manajemen rumah sakit, sedangkan niat untuk menggunakan teknologi berpengaruh terhadap perilaku menggunakan teknologi pada sistem informasi manajemen rumah sakit di RS Ortopedi Prof. Dr. R. Soeharso Surakarta.

Kata kunci: Technology Acceptance Model (TAM), Sistem Informasi Manajemen, Rumah Sakit

\section{Pendahuluan}

Sistem informasi manajemen adalah sistem informasi yang banyak menghasilkan berbagai informasi atau laporan untuk keperluan pengambilan keputusan oleh manajer. Saat ini RSO Prof. dr. R. Soeharso sudah menggunakan sistem komputerisasi dalam pengolahan data dan informasi mandiri untuk pengadaan hardware, software dan pembinaan brainware. Sistem Informasi Manajemen Rumah Sakit (SIMRS) di RSO Prof. dr. R. Soeharso berbasis komputer sudah dilaksanakan sejak tahun 2008 dengan dua kali pergantian sistem dengan pihak ketiga, dan sejak 1 Desember 2013 RSO Prof. dr. R. Soeharso sudah menggunakan sistem untuk menjalankan organisasi dimana dikenal dengan nama Sistem Informasi Manajemen Rumah Sakit (SIMRS). Perangkat lunak SIMRS Mandiri dirancang dan dikembangkan oleh tim Teknologi Informasi (TI) dari RS Ortopedi. Pengguna (user) SIR Mandiri adalah manajemen operasional yang terdiri dari koordinator dan staf pendaftaran pasien baik rawat jalan maupun rawat inap, kepala ruang dan perawat ruang, administrasi bangsal, staf dan petugas administrasi bagian penunjang, instalasi farmasi serta kasir rumah sakit.

Surat Keputusan Menkes RI No 228/2002 tentang Pedoman Penyusunan Standart Pelayanan Minimal Rumah Sakit menyatakan bahwa rumah sakit memerlukan dukungan SIMRS yang handal untuk memberikan pelayanan kesehatan yang standar kepada masyarakat. Informasi Manajemen Rumah Sakit (SIMRS) di RSO Prof. dr. R. Soeharso dengan menggunakan Technology Acceptance Model (TAM). Penggunaan model TAM didasarkan pada pendapat Venkatesh (2000) yang menyatakan bahwa sejauh ini TAM merupakan sebuah konsep yang dianggap paling baik dalam menjelaskan perilaku user terhadap sistem teknologi informasi baru. Menurut Venkatesh (2000) TAM secara empiris terbukti menjelaskan $40 \%$ usage intensions dan behavior.

Secara teoritis dan praktis TAM merupakan model yang dianggap paling tepat dalam menjelaskan bagaimana user menerima sebuah sistem. TAM menyatakan bahwa behavioral intension to use ditentukan oleh dua keyakinan yaitu: pertama, perceived usefulness yang didefinisikan sebagai sejauh mana seseorang yakin bahwa menggunakan sistem akan meningkatkan kinerjanya. Kedua, perceived ease of use yang didefinisikan sebagai sejauh mana seseorang yakin bahwa penggunaan sistem adalah mudah. TAM juga menyatakan bahwa dampak variabel-variabel eksternal terhadap intension to use adalah dimediasi oleh perceived of usefulness dan perceived ease of use. Konsep TAM juga menyatakan bahwa perceived usefulness dipengaruhi oleh perceived ease of use.

Penelitian ini penting dilakukan mengingat perubahan sistem informasi manajemen rumah sakit (SIMRS) dari sistem lama hasil kerjasama dengan pihak ketiga ke sistem baru yang merupakan sistem mandiri yang dikembangkan oleh Tim IT RSO Prof. dr. R. Soeharso memerlukan proses transisi, yang bagi beberapa karyawan menimbulkan konflik dalam proses adaptasi.

\section{Tinjauan Pustaka}

Teori yang membahas mengenai kesiapan penggunaan teknologi disebut dengan Tecnology Acceptance Model (TAM) 
yang ditemukan oleh Davis. Technology Acceptance Model (TAM) merupakan alat teoritis yang baik (Park, 2009), popular (Priyanka dan Kumar, 2013, dan menawarkan suatu penjelasan yang kuat serta sederhana untuk penerimaan dan perilaku para penggunanya. Terdapat dua faktor penentu yang sangat penting dalam menggunakan teknologi informasi, yaitu persepsi mengenai manfaat (Perccieved Usefulness) dan persepsi mengenai kemudahan dalam menggunakan teknologi (Perceived Ease of Use) didefinisikan sebagai sejauhmana seseorang percaya bahwa menggunakan suatu teknologi adalah mudah dan tidak membutuhkan usaha yang lebih besar pada saat digunakan (Davis, 1989).

Kajian liteatur mengindikasikan bahwa self efficacy menentukan persepsi manfaat (Rose dan Fogarty, 2006). Aksesibiliti ditemukan menjadi faktor penting dalam membina sikap positif (Chau dan Lai 2003), dan persepsi kemudahan penggunaan teknologi (Venkatesh, 2000; Rose dan Fogarty, 2006), dan memiliki pengaruh positif terhadap persepsi kemudahan penggunaan teknologi (Yusuf et al, 2009; Abramson, 2015). Persepsi manfaat memiliki koreksi signifikan lebih besar dengan perilaku penggunaan dari pada persepsi kemudahan penggunaan teknologi (Davis, 1989) dan memiliki hubungan yang positif dengan sikap dalam menggunakan teknologi (Abramson, 2015). Persepsi kemudahan penggunaan teknologi mempunyai hubungan signifikan dan positif terhadap persepsi manfaat (Yusuf et al, 2009; Abramson, 2015), meningkatkan persepsi manfaat (Lin dan Chang, 2011; Abramson, 2015), dimana sikap dalam menggunakan teknologi menjadi penentu yang signifikan dari niat perilaku untuk menggunakan teknologi (Teo et al,. 2008; Suki dan Suki, 2011) dan mempunyai hubungan positif dengan niat perilaku (Lin dan Chang, 2011) untuk menggunakan teknologi. Faktorfaktor penentu yang dirasakan kemudahan penggunaan, pendorong utama penerimaan teknologi, adopsi, dan perilaku penggunaan
(Venkatesh, 2000).

Kajian literatur mengindikasikan bahwa subjectivenorms menentukan persepsimanfaat (Schepers, 2007), memiliki efek positif dengan Perceived Ease of Use (Abramson, 2015). Sejauh ini penelitian telah dilakukan untuk mengidentifikasi konstruk yang membangun Tecnology Acceptance Model (TAM). Hasil menunjukan bahwa persepsi manfaat dan persepsi kemudahan penggunaan teknologi (Davis, 1989, Davis et al, 1989, Venkatesh, 2000, Rose dan Fogarty, 2006, Teo et al, 2008, Park,2009, Yussof et al, 2009, Suki dan Suki, 2011, Abramson, 2015), sikap (Davis et al, 1989., Hu, 1999., Teo et al, 2008., Park, 2009., Suki dan Suki, 2011., Abramson, 2015, dan niat untuk menggunakan teknologi (Davis et al,. 1989., Hu, 1999., Venkatsh, 2000 ., Rose dan Fogarty, 2006., Teo et al., 2008., Park, 2009., Suki dan Suki, 2011., Abramson, 2015) menjadi sebuah konstruk yang membangun aplikasi Tecnology Acceptance Model (TAM). Perilaku Niat langsung mempengaruhi perilaku menggunakan (Attuquayefio, 2014).

\section{Metode Penelitian}

Penelitian ini merupakan penelitian empiris dengan metode kuantitatif. Jenis data yang digunakan data primer. Populasi seluruh karyawan yang menggunakan sistem informasi manajemen sebanyak 382 orang, sampel 193 orang dengan teknik sample random sampling. Instrumen penelitian menggunakan kuesioner dengan skala linkert. Analisa data meliputi uji validasi, reliabilitas dan analisa jalur Path. Uji asumsi model meliputi uji normalitas, outliers, estimasi model dan interprsetasi serta multiple model.

\section{Hasil Dan Pembahasan}

Berdasarkan hasil analisis dengan Analisis Jalur (Path) yang diolah dengan program AMOS versi 16.0 diketahui bahwa nilai dari masing-masing antar variabel menunjukkan pengaruh yang positif dan signifikan. Hal ini merupakan pembuktian hipotesis pertama $\left(\mathrm{H}_{1}\right)$ bahwa computer self efficiacy berpengaruh positif terhadap persepsi 
manfaat teknologi terbukti kebenarannya $(\mathrm{E}=$ $0,796 ; \rho=0,000)$. Hipotesis kedua $\left(\mathrm{H}_{2}\right)$ bahwa computer self efficiacy berpengaruh positif terhadap persepsi kemudahan menggunakan teknologi terbukti kebenarannya $(\mathrm{E}=0,840$; $\rho=0,006)$. Hipotesis ketiga $\left(\mathrm{H}_{3}\right)$ bahwa Subjective norm berpengaruh positif terhadap persepsi manfaat terbukti kebenarannya (E $=0,696 ; \rho=0,000)$. Hipotesis keempat $\left(\mathrm{H}_{4}\right)$ bahwa Subjective norm berpengaruh positif terhadap persepsi kemudahan menggunakan teknologi terbukti kebenarannya $(\mathrm{E}=0,698 ; \rho$ $=0,015)$. Hipotesis kelima $\left(\mathrm{H}_{5}\right)$ bahwa System accessibility berpengaruh positif terhadap persepsi manfaat tidak terbukti kebenarannya $(\mathrm{E}=0,273 ; \rho=0,334)$. Hipotesis keenam $\left(\mathrm{H}_{6}\right)$ bahwa System accessibility berpengaruh positif terhadap persepsi kemudahan menggunakan teknologi terbukti kebenarannya $(\mathrm{E}=0,311$; $\rho=0,034)$.

Adapun hipotesis ketujuh $\left(\mathrm{H}_{7}\right)$ bahwa persepsi kemudahan penggunaan teknologi berpengaruh positif dan signifikan terhadap persepsi manfaat terbukti kebenarannya (E $=0,382 ; \rho=0,048)$. Hipotesis delapan $\left(\mathrm{H}_{8}\right)$ bahwa persepsi manfaat berpengaruh positif signifikan terhadap sikap untuk menggunakan teknologi terbukti kebenarannya $(\mathrm{E}=0,724$; $\rho=0,024)$.

Hipotesis sembilan $\left(\mathrm{H}_{q}\right)$ bahwa persepsi kemudahan penggunakan teknologi berpengaruh positif signifikan terhadap sikap untuk menggunakan teknologi terbukti kebenarannya $(E=0,617 ; \rho=0,011)$. Hipotesis sepuluh $\left(\mathrm{H}_{10}\right)$ bahwa sikap berpengaruh positif signifikan terhadap niat untuk menggunakan teknologi terbukti kebenarannya $(\mathrm{E}=0,577 ; \rho$ $=0,0291)$, dan hipotesis sebelas $\left(\mathrm{H}_{11}\right)$ bahwa niat berpengaruh positif tidak signifikan terhadap pewrilaku menggunakan teknologi tidak terbukti kebenarannya $(\mathrm{E}=0,317 ; \rho=$ 0,081).

Persepsi kemudahan penggunaan teknologimerupakan ukuran dimana seseorang yakin bahwa komputer dapat dipahami dan digunakan dengan mudah (Davis, 1989). Individu dengan self efficacy rendah akan merusak motivasi melalui perasaan bahwa mereka tidak mampu untuk menyelesaikan tugas itu, sebelum tugas tersebut dicobanya. Self efficacy memeliliki tiga dimensi yang mempunyai implikasi penting pada kinerja, yaitu Magnitude atau level, generality, dan strength (Badura, 1977). Magnitude atau level merupakan persepsi seorang individu mengenai kemampuanya dalam menghasilkan tingkah laku melalui tingkat tugas yang menunjukan kesulitan tugas. Individu yang memiliki tingkat keyakinan tinggi bahwa dia mampu mengerjakan tugastugas walaupun sulit berarti memiliki self efficacy yang tinggi, sedangkan individu yang memiliki tingkat keyakinan rendah bahwa dia hanya mampu mengerjakan tugas-tugas yang mudah berarti memiliki self efficacy yang rendah pula, sehingga membenarkan $\mathrm{H}_{1}$. Hasil penelitian ini konsisten dengan penelitian yang dilakukan Venkatesh (2000), Rose dan Fogarty (2006), Yusof et al, (2009), dan Abramson (2015) menemukan bahwa computer self efficacy berpengaruh positif terhadap persepsi kemudahan penggunaan.

Kondisi kedua membuktikan pengaruh yang signifikan antara computer self effiacy sudah sesuai $(b=0,840, p=0,006)$, sehingga membenarkan $\mathrm{H}_{2}$. Dalam menampilkan suatu perilaku perlu adanya pemikiran dari individu lain yang akan dijelaskan melalui norma subyektif. Planned behavior theory memperhatikan elemen social dari perilaku seseorang individu melalui norma subyektif ini (Ajzen,1991). Secara spesifik, dalam planned behavior theory norma sbyektif tentang suatu perilaku (subjective norm) didefinisikan sebagai persepsi individu tentang tekanan social untuk melakukan atau tidak melakukan suatu perilaku. Hasil penelitian ini didukung oleh penelitian yang dilakukan oleh Venkatesh (2000), Rose dan Fogarty (2006), Yusof et al, (2009), dan Abramson (2015) menemukan bahwa computer self efficacy berpengaruh positif terhadap persepsi kemudahan penggunaan.

Kondisi ketiga membuktikan pengaruh yang signifikan antara subjective norms sudah sesuai $(b=0,696, p=0,000)$, sehingga 
membenarkan $\mathrm{H}_{3}$. Hal ini dapat dikatakan bahwa ketika individu mempersepsikan bahwa rujukan sosialnya merekomendasikan untuk melakukan suatu perilaku maka individu akan cenderung merasakan tekanan sosial untuk melakukan perilaku tersebut, sebaliknya semakin individu mempersepsikan bahwa rujukan sosialnya merekomendasikan untuk tidak melakukan suatu perilaku maka individu akan cenderung merasakan tekanan sosial untuk tidak melakukan perilaku tersebut (Ajzen, 2005 dikutip dalam Wong 2012). Norma subjektif merupakan pandangan individu tentang tekanan social (pendapat orang lain) untuk melakukan atau tidak melakukan suatu tindakan atau perilaku. Seseorang akan cenderung melakukan suatu perilaku apabila pendapat sosial atau rujukan sosialnya mengarahkannya untuk melakukan perilaku tersebut. Subjective normn ditemukan memiliki efek langsung positif pada perceived use melalui efek internalisasi di Amerika Utara (Venkatesh dan Davis, 2000). Wong (2015), norma subjektif memiliki efek langsung pada kegunaan yang dirasakan, Ditemukan bahwa persepsi kemudahan penggunaan memiliki dampak yang signifikan terhadap sikap untuk menggunakan (ATU) di padu dengan penelitian sebelumnya (Davis 1989). Priyanka dan Kumar (2014) persepsi kemudahan penggunaan (PEOU) juga memiliki dampak yang signifikan pada kegunaan yang dirasakan, menemukan pengaruh yang signifikan antara manfaat yang dirasakan (PU), Sikap terhadap penggunaan (ATU) dan niat perilaku (ITU) untuk menggunakan e-rekrutmen Sistem.

Kondisi keempat membuktikan pengaruh yang signifikan antara subjective norms dengan persepsi kemudahan penggunaan teknologi sudah sesuai $(b=0,698, p=0,015)$, sehingga membenarkan $\mathrm{H}_{4}$ Ini berarti persepsi kemudahan penggunaan teknologi merupakan ukuran dimana seseorang yakin bahwa komputer dapat dipahami dan digunakan dengan mudah (Davis, 1989). Subjective norms mengacu pada tekanan sosial yang dihadapi oleh individu untuk melakukan atau tidak melakukan sesuatu (Lo Choi Tung,
2011). Hasil penelitian ini sejalan dengan penelitian yang dilakukan oleh Abramson (2015), Davis (1989), Davis et al (1989), Hu (1999), Venkatesh ( 2000), Rose dan Fogarty (2006), Park (2000) dan Suki dan Suki, (2011) menemukan bahwa Subjective norms berpengaruh positif terhadap kemudahan penggunaan.

Kondisi kelima membuktikan pengaruh yang signifikan antara system accessibility dengan persepsi manfaat kurang sudah sesuai $(b=0,273, p=0,334)$, sehingga kurang membenarkan $\mathrm{H}_{5}$. Lin dan $\mathrm{Lu}$ (2000) melaporkan bahwa akses informasi yang lebih tinggi membawa tentang penggunaan yang lebih tinggi dari informasi dan persepsi yang lebih tinggi dari kemudahan penggunaan. Dalam studi ini, e-learning aksesibilitas mengacu pada tingkat kemudahan yang seorang mahasiswa dapat mengakses dan menggunakan sistem e-learning kampus sebagai faktor organisasi. Secara khusus, personalisasi, jasaaliansi, tugas keakraban, dan aksesibilitas ditemukan memiliki pengaruh signifikan pada kegunaan yang dirasakan atau persepsi kemudahan penggunaan, yang, pada gilirannya, ditemukan menjadi faktor penting dalam membina sikap positif terhadap menerima layanan. beberapa implikasi untuk penelitian dan praktek muncul dan kini dibahas. Hasil penelitian ini kurang konsisten dengan penelitian yang dilakukan oleh Lee et all (2014) bahwa variabel kunci (PU dan PEU) dan variabel eksternal (teknologi aksesibility) harus dianggap sebagai faktor penting dalam proses merancang, melaksanakan dan e-learning operasi sistem di Indonesia khususnya di RSO Profdr. Soeharso Surakarta.

Kondisi keenam membuktikan pengaruh yang signifikan antara system accessibility dengan persepsi kemudahan penggunaan teknologi sudah sesuai $(b=0,311$, $\mathrm{p}=0,034)$, sehingga kurang membenarkan $\mathrm{H}_{6}$. Hasil penelitian ini didukung oleh penelitian yang dilakukan oleh Karahanna dan Straub [2094]. di studi mereka, aksesibilitas adalah multidimensi meliputi baik fisik akses terminal dan kemampuan penggunaan 
sistem. Mereka berpendapat bahwa sebuah lebih mudah diakses sistem informasi, upaya kurang dibutuhkan untuk menggunakannya. Dalam konteks perbankan, aksesibilitas mengacu tidak hanya aksesibilitas fisik koneksi internet, tetapi juga bersifat global dan round-the-clock internet banking. Goh [1995] berpendapat bahwa jika infrastruktur teknologi pendukung yang mudah dan tersedia, aplikasi Internet commerce seperti internet banking akan menjadi lebih layak. Tan dan Teo [1996] sependapat dengan argumen ini dan mendalilkan bahwa aksesibilitas internet banking adalah fasilitator adopsi karena yang kapasitas yang memungkinkan pengguna untuk melihat teknologi lebih menguntungkan.

Kondisi ketujuh membuktikan pengaruh yang signifikan antara persepsi kemudahan penggunaan tekologi dengan persepsi manfaat penggunaan teknologi sudah sesuai $(\mathrm{b}=$ $0,334, p=0,022)$, sehingga membenarkan $\mathrm{H}_{7}$ Menurut Chau dan Lai (2003), bahwa persepsi kemudahan penggunaan mungkin yang paling penentu signifikan penerimaan pengguna internet banking. Ini juga menunjukkan atau menegaskan pentingnya peran persepsi kemudahan penggunaan dalam tahap adopsi awal dari teknologi baru. Persepsi manfaat merupakan suatu ukuran dimana pengguna teknologi dipercaya akan mendatangkan manfaat bagi orang yang menggunakannya (Davis, 1989). Hasil penelitian ini diperkuat oleh penelitian yang dilakukan oleh Lin dan Chang (2011), Abramson (2015) dengan hasil penelitiannya bahwa persepsi kemudahan berpengaruh terhadap persepsi manfaat.

Kondisi kedelapan membuktikan pengaruh yang signifikan antara persepsi manfaat terhadap sikap untuk menggunakan teknologi $(b=0,391, p=0,028)$, sehingga membenarkan $\mathrm{H}_{8}$. Menurut Davis (1989), Perceived Ease of Use adalah tingkatan dimana seseorang percaya bahwa menggunakan suatu sistem tertentu bebas dari usaha. Hal yang paling penting bagi pengguna adalah jumlah usaha yang dia keluarkan untuk dikeluarkan dalam menggunakan suatu sistem. Kemudahan penggunaan adalah konsep yang telah mendapatkan perhatian dalam kepuasan pengguna dalam alirannya penelitian sistem informasi. Menurut Davis (1989), segala sesuatu yang sama, sistem yang mudah digunakan akan meningkatkan niat untuk menggunakan sebagai kebaikan dari suatu sistem yang lebih mudah digunakan. Mempertimbangkan argument yang jelas usaha individu untuk menjadi sumber daya langka, sedemikian hingga seseorang individu seharusnya rela untuk mengalokasikan lebih banyak kesempatan dari pada sistem yang memerlukan usaha lebih besar. Hal ini semakna dengan penelitian yang dilakukan oleh Iqbaria (1994) yang menguji tentang penerimaan penggunaan mikro komputer dipengaruhi oleh kemudahan penggunaan yang diharapkan oleh sipengguna atau karena tekanan sosial. Temuan studi Iqbaria (1994) membuktikan bahwa TI digunakan bukan mutlak karena adanya tekanan sosial, sehingga dapat simpulkan bahwa penggunaan TI bukan karena adanya unsure tekanan, tetapi karena memang mudah digunakan.

Kondisi kesembilan membuktikan pengaruh yang signifikan antara persepsi kemudahan penggunaan teknologi terhadap sikap untuk menggunakan teknologi $(\mathrm{b}=$ $0,402, \mathrm{p}=0,016$ ), sehingga membenarkan $\mathrm{H}_{9}$ Menurut Davis et al (1989) menjelaskan bahwa sikap dalam menggunakan teknologi diartikan sebagai cermin dari perasaan suka atau tidak suka terhadap suatu sistem dari target perilaku yang telah dilakukan. Semakna dengan penelitian yang dilakukan oleh Abramson (2015) yang menemukan bahwa persepsi manfaat berpengaruh terhadap sikap. Mereka juga menemukan bahwa persepsi kemudahan penggunaan berpengaruh terhadap sikap.

Kondisi kesepuluh membuktikan pengaruh yang signifikan antara sikap terhadap niat untuk menggunakan teknologi $(b=0,518, p=0,028)$, sehingga membenarkan $\mathrm{H}_{10}$. Niat untuk menggunakan teknologi merupakan keinginan perilaku pengguna untuk menggunakan system informasi. Penelitian Klopping and McKinney (2004) 
menemukan hasil bahwa keinginan seseorang untuk menggunakan suatu system dipengaruhi oleh manfaatnya, sedangkan penelitian Suki (2011) menemukan bahwa sikap berpengaruh terhadap niat untuk menggunakan teknologi. Hal ini didukung juga oleh penelitian yang dilakukan oleh Abramson (2015)bahwa sikap dalam menggunakan teknologi menjadi penentu yang signifikan dari niat perilaku (Teo et al, 2008; Suki, 2011; Venkatesh, 2000) dan mempunyai hubungan positif dengan niat perilaku (Venkatesh, 2000) untuk menggunakan teknologi.

Kondisi kesebelas membuktikan pengaruh yang signifikan antara niat terhadap perilaku menggunakan teknologi $(b=0,433$, $\mathrm{p}=0,0306)$, sehingga membenarkan $\mathrm{H}_{11}$. Menurut Venkatesh et al., (2003), bahwa niat merupakan proses kognitif kesiapan individu untuk melakukan perilaku tertentu dan merupakan anteseden langsung dari perilaku penggunaan. Pada gilirannya, perilaku pengguna adalah tindakan diamati dilakukan oleh seorang individu berdasarkan pengalaman mereka atau dimediasi oleh beberapa pengamatan perwakilan dari target / tingkat tertentu Dampak BI pada BU mendapat dukungan yang kuat dalam literatur (misalnya, Shih \& Fang, 2004; Taylor \& Todd, 1995a; Venkatesh et al, 2003;. Tarhini et al, 2015a). Di samping itu penelitian ini diperkuat oleh penelitian yang dilakukan oleh Abbasi, at el, (2015), dimana sistem informasi PBC tetap merupakan konstruk penting dari BI dan BU. Misalnya, menggunakan TPB, DTPB, dan A-TAM, peneliti (misalnya, Chau \& Hu, 2001; Shih \& Fang, 2004) menemukan dampak yang signifikan dari PBC pada BI, sedangkan dengan menggunakan model yang sama, orang lain (Mathieson, 1991; Taylor \& Todd, 1995b) menemukan dampak yang signifikan dari PBC pada BU.

Untuk memperkuat pembuktian hipotesis yang telah ada, maka dapat diperkuat oleh analisis jalur dengan analisis Structural Equation Modelling (SEM) yang diolah dengan program AMOS versi 16.0 tersebut diketahui bahwa self efficacy, subjective norm, system accessibility, persepsi manfaat, persepsi kemudahan dalam menggunakan teknologi, sikap dalam menggunakan teknologi, niat dalam menggunakan teknologi berpengaruh terhadap perilaku menggunakan teknologi.

\section{Penutup}

Berdasarkan hasil penelitian, maka peneliti dapat menyimpulkan beberapa hal sebagai berikut. Computer selt efficacy berpengaruh terhadap persepsi manfaat dan persepsi kemudahan penggunaan teknologi pada sistem informasi manajemen rumah sakit. Subjective norms berpengaruh terhadap persepsi manfaat dan persepsi kemudahan penggunaan teknologi pada sistem informasi manajemen rumah sakit. System accessibility tidak berpengaruh terhadap persepsi manfaat, namun berpengaruh terhadap persepsi kemudahan penggunaan teknologi pada sistem informasi manajemen rumah sakit. Persepsi kemudahan berpengaruh terhadap persepsi manfaat pada sistem informasi manajemen rumah sakit. Persepsi manfaat dan persepsi kemudahan penggunaan teknologi tidak berpengaruh terhadap sikap menggunakan teknologi pada sistem informasi manajemen rumah sakit. Sikap dalam menggunakan teknologi berpengaruh terhadap niat untuk menggunakan teknologi pada sistem informasi manajemen rumah sakit, sedangkan niat untuk menggunakan teknologi berpengaruh terhadap perilaku menggunakan teknologi pada sistem informasi manajemen rumah sakit di RS Ortopedi Prof. Dr. R. Soeharso Surakarta. 


\section{Daftar Pustaka}

Abbasi, M. S., Chandio, F. H., Soomro, A. F., \& Shah, F. 2011. "Social influence, voluntariness, experience and the internet acceptance: An extension of technology acceptance model within a south-Asian country context" Journal of Enterprise Information Management, 24(1), 30-52.

Abramson, J; Dawson, M dan Stevens. 2015. An Examination of the Prior Use of E-Learning Within an Extended Technology Acceptance Model and the Factors that Influence the Behaviorar Intention of Users to Use M-Learning. SAGE Open.1-9.

Ahlan, A.R and B. I. Ahmad, B.I. 2015. "An Overview of patient of Health Information Technology (HIT) in Developing Countries: A review and Conceptual Model," Procedia Technology, vol. 3. No. 1, 29-48.

Ajzen, I. "The Theory of Planned Behavior," Organizational Behavior and Human Decision Processes (50:2), December 1991, pp. 179-21 1.

Attuquayefio, S.N. 2014. "Using the UTAUT Model to Analyze Students'ICT Adoption". International Journal of Education and Development Using Information and Communication Technology. Vol. 10, Issue 3: 75-86.

Badura, A. 1977. "Self-Efficacy: Toward a Unifying Theory of Behavioral Change". Psychological Review. Vol, 64. No. 2: 191-215.

Badura, A. 1983. "Self-Efficacy Determinants of Anticipated Fears and Calamities". Journal of Personality and Social Psychology, Vol. 45, No. 2, 464-469

Bandura, A. (1994). Self-efficacy. In V. S. Ramachaudran (Ed.), Encyclopedia of human behavior (Vol. 4, pp. 71-81). New York: Academic Press. (Reprinted in H. Friedman [Ed.], Encyclopedia of mental health. San Diego: Academic Press, 1998).

Chau, P.Y.K dan Hu, P.J.H. 2001. "Information Technology Acceptance by Individual Professionals: A Model Comparison Approch.” Decision Sciences. Vol. 32, No. 4: 699716.

Davis, F.D. 1989. "Perceived Usefulness, Perceived Ease ofUse, and User Acceptance of Information Technology". Management Information Systems Research Center. Vol.13, No. 3:319-340.

Davis, F.D. 1993. "User Acceptance of Information Technology: System Characteristics, User Perceptions and Behavioral Impacts". Int. J.Man-Machine Studirs, 38: 475-487.

Davis, F.D, R. P. Bagozzi, P. R. Warshaw. 1989. User acceptance of computer technology: A comparison of two theoretical models". Management Sci. 35(8) 982-1002.

Ghozali, I. 2008. Model Persamaan Struktural Konsep dan Aplikasi dengan Program Amos 16.0, Semarang: Badan Penerbit UNDIP.

Hair, J.F., R. Anderson R.E., Tatham, R.L. and Black, W. C. 1998., Multivariate Data Analysis. London: Prentice-Hall, International

Hu, P. J., Chau, P. Y. K., Liu, S. O. R., \& Tam, K. Y. (1999). "Examining the technology acceptance model using physician acceptance of telemedicine technology". Journal of Management Information Systems, 16, No.2: 91-112.

Khairi, M.S dan Baridwan, Zaki. 2015. "An EmpiricalStudy on Organizational Acceptance 
Accounting Information System in Sharia”. The International Journal of Accounting and Business Society. Vol. 23, No. 1: 97-122.

Lee, YH; Hsiao, C dan Purnomo,S.H. 2014. "An Empirical Examination of Individual and System Characteristics on Enhancing E-Learning Acceptance". Australasian Journal of Educational Technology. 30(5): 562579.

Lubis, R.N dan Otok, B.W. 2011. Pengaruh Kepribadian Terhadap Perilaku Kewirausahaan Menggunakan Partial Least Square. (belum lengkap)

Melas, C.D., L.A. Zampetakis, A. Dimopoulou \& V. Moustakis (2011). "Modeling the acceptance of clinical information systems among hospital medical staff: An extended TAM model". Journal of Biomedical Informatics, 44(4), 553-64.

Notoatmodjo, S. 2002. Metodologi Penelitian Kesehatan. Jakarta; Rineka Cipta.

Park, S. Y. 2009. "An analysis of the Technology Acceptance Model in understanding university students' behavioral intention to use e-Learning." Educational Technology \& Society, $12(3), 150-162$.

Priyanka, S dan Kumar, M.A. 2014. "Astudy on Adoption of E-Reccrukment Using TechnologyAcceptanceModel (TAM) With Reference to Graduating Students in Iniversitiesin Bahrain." International Journal ofAdvanceResearch in ComputerScienceandManagement Studies. Vol,2, Issue 9: 2321-7782.

Rose, J dan Fogarty, G. 2006. "Determinants of Perceived Usefulness and Perceived Easeof Use in the Technology Acceptance Model: Senior Consumers' Adoption of Self- Service Banking Technologies". Academy of Business, Marketing and Management Development Conference Procedings. Vol, 2, No.10:122-128.

Schepers, J., \&Wetzels, M. (2007). "A meta-analysis of the technology acceptance model: Investigating subjective norm and moderation effects". Information \& Management, 44, 90-103.

Sugiyono. 2005. Metode Penelitian Bisnis. Bandung: CV Alfabeta.

Suki, N.M dan Suki, N.M. 2011.’Exploring the Relationship Between Perceived Usefulness, Perceived Ease of Use, Perceived Enjoyment, Attitude and Subscribers' Intention Towards Using 3G Mobile Services". Journal of Information Technology Management. Vol. XXII, No. 1:1-7.

Taylor, S. and Todd, P. "Understanding lnformation Technology Usage: A Test of Competing Models," Information Systems Research (6:2), June 1995, pp. 144- 176.

Venkatesh, F. D. Davis. 1996. “A model of the antecedents of perceived ease of use: Development and test”. Decision Sci. 27(3) 451-481.

- -2000 . "A theoretical Extension of the Technology Acceptance Model: Four Longitudinal Field Studies". Management Sci. 46 186-204.

Venkatesh, V, Morris, M.G. Davis, G.B dan Davis, F.D. 2003."User Acceptance of Information Technology: Toward a Unified View”. MIS Quarterly, Vol. 27, No. 3 :425-478.

Venkatesh,V. (2000) "Determinants of Perceived Ease of Use: Integrating Perceived Behavioral Control, Computer Anxiety and Enjoyment into the Technology Acceptance Model". Information Systems Research, Vol.11 No.1, pp.342-365. 
Venkatesh, V. and Bala, H. 2008. "Technology Acceptance Model 3 and a Research Agenda on Interventions." Decision Sciences 39, 273-315.

Wong, G.K.W. 2015. "Understanding Technology Acceptance in Pre-Service Teachers of Primary Mathematics in Hong Kong." Australasian Journal of Aducational Technology. Vol 31, No. 6: 713735 